Garner, J., W. Iwasko, M. Kidwell, K. Rogacheski, R. Aylward, and J. Anderson, 2019: Cool season small hail over the west coast of the United States: environments, hazards, and decision support. J. Operational Meteor., 7 (6), 78-91, doi: https://doi.org/10.15191/nwajom.2019.0706

Journal of Operational Meteorology
Article

\title{
Cool Season Small Hail over the West Coast of the United States: Environments, Hazards, and Decision Support
}

\author{
JONATHAN GARNER, WILLIAM IWASKO, MATTHEW KIDWELL, KARLEISA ROGACHESKI, AND RYAN AYLWARD \\ National Weather Service Forecast Office, Eureka, CA \\ JASON ANDERSON \\ National Weather Service, Center Weather Service Unit, Minneapolis, MN
}

(Manuscript received 27 October 2018; review completed 10 April 2019)

\begin{abstract}
National Weather Service (NWS) forecasters across the west coast of the United States often deal with cool season hail showers that produce hazardous driving conditions. These small hail events, with diameters averaging $5.8 \mathrm{~mm}$, occur with cold upper troughs that support weak instability favorable for low-topped convection and reflectivity values averaging $48 \mathrm{dBZ}$. The public generally assumes that heavy snow is common across west coast mountains, while heavy rain prevails near sea level. However, motorists can be caught offguard when wet, relatively warm low elevation roadways suddenly transition to icy hail-covered conditions. Thus, west coast small hail events represent an opportunity for the NWS to provide tailored messaging that can modify public perceptions and optimize outcomes. This research examines environments supportive of accumulating small hail over the western United States during the period 2008-2018, and supplements the environmental analysis with a summary of enhanced impact-based decision support techniques used to alert NWS partners and the general public.
\end{abstract}

\section{Introduction}

Cool season weather hazards over the west coast of the United States consist of heavy rain, flooding, and mudslides associated with atmospheric rivers (Ralph et al. 2004, Ralph et al. 2018), heavy mountain snow (Steenburgh 2003), high winds (Mass and Dotson 2010), fog (Holets and Swanson 1981, Ashley et al. 2015), and severe thunderstorms (Blier and Batten 1994), all of which can negatively impact public safety and commerce. These hazards are well documented, and are explicitly addressed in National Weather Service (NWS) watches, warnings, and advisories. On the other hand, small hail is a cool-season weather phenomenon that has received little published attention, and its occurrence is ambiguously conveyed in NWS products. However, small hail results in hazardous travel conditions every year when it accumulates on west coast roadways. Thus, small hail needs to be addressed by the meteorological community.

Initial research efforts by Kalina et al. (2016) addressed plowable hail events in Colorado consisting of stones with diameters ranging from 12.7 to $44.5 \mathrm{~mm}$. These episodes were associated with radar reflectivity (Z) values from 68-75 dBZ, differential reflectivity values from $0 \mathrm{~dB}$ to $-4 \mathrm{~dB}$, prominent three-body scattering, and well-defined bounded weak echo regions (BWER; Chisholm 1973, Lemon 1980). These radar characteristics are generally associated with longlived storms such as supercells and organized multicells (Rotunno and Klemp 1985), which contribute toward plowable hail events by yielding unusually long hailfall durations (9-28 $\mathrm{min}$ ) and large hail mass concentrations ( $\mathrm{Z} \geq 68 \mathrm{dBZ}$ ).

Of greater relevance to cool season small hail over the west coast, Takahashi et al. (1995) found that ice particle production is maximized at temperatures near $-16^{\circ} \mathrm{C}$, with high ice particle concentrations possibly 
occurring because of breaking of ice branches grown through deposition on ice spheres. Those results support the hypothesis of Takahashi (1993), who postulated that ice crystals are generated by collisions between large graupel produced in the upper levels of a cloud through riming, and small graupel forming in the low levels through deposition. This results in large ice particle concentrations within maritime convective clouds, which are characterized by weak updrafts and limited supercooled liquid water content.

The primary motivation for the current study is to improve operational prediction of small hail through a detailed examination of past small hail environments. However, a second goal was to compile and share impact-based decision support (IDSS) methods used by west coast NWS offices when small hail is occurring or anticipated. These IDSS procedures assist NWS partners, such as law enforcement, road departments, and emergency operation centers in the fulfillment of their mission. In addition, IDSS can be used to incite an appropriate public response through targeted messaging that modifies perceptions and expectations. Research into public perceptions, expectations, and decision making related to hazardous weather continues to increase. Examples of such literature exist for hurricanes (Meyer et al. 2014, Rickard et al. 2017), tornadoes (Jaunernic and Van Den Broeke 2016), and floods (Becker et al. 2015).

In order to ensure that the societal response is equal to the risk their community faces, the NWS keeps local, state, and federal government agencies informed of updated weather developments, and communicates detailed information beyond traditional NWS forecast products. This is IDSS in action (NWS 2018). Several examples of IDSS activities have been documented in the literature. Lindley et al. (2016) demonstrated the utility of using text- and graphical-based communication strategies to alert fire weather partners of satellite-detected fire ignitions, which resulted in a more rapid and efficient response to emerging wildfire threats. IDSS has also been employed during severe weather events. For example, advancements in radar technology, and an increased understanding of tornadogenesis, has led the NWS to issue impactbased tornado warnings when strong and violent tornadoes have been detected in real-time (Obermeirer and Anderson 2015). Other projects such as FACETS (Rothfusz et al. 2018) aim to "reinvent the NWS hazard forecasting and communication paradigm" in order to "deliver multiscale user-specific probabilistic guidance from numerical weather prediction ensembles." These examples show that a concerted effort is being made within the NWS to provide enhanced guidance that aids decision making by sophisticated users, while at the same time tailoring public messaging in order to optimize outcomes during hazardous weather events.

The purpose of this paper is to 1) aid forecaster identification of impactful accumulating small hail environments, and 2) provide an overview of small hail IDSS strategies that can be used to alert NWS partners and the public. Section two will describe the methods used to carry out the study. Section three will present results on the hazards and environments associated with small hail, while section four examines IDSS techniques employed across a variety of west coast NWS offices during small hail events. The paper will be concluded with a summary and discussion in section five.

\section{Methodology}

The National Oceanic and Atmospheric Administration Storm Data database, NWS local storm reports ${ }^{1}$, CoCoRaHS (Cifelli et al. 2005), highway patrol reports, and online newspaper articles were examined for hailstones with diameters $\leq 19 \mathrm{~mm}$ occurring in the states of Washington, Oregon, and California from 2008 to 2018. This search yielded 880 "small hail" events whose average diameter was $5.8 \mathrm{~mm}$. Roughly $6 \%$ of the 880 small hail events identified were associated with impacts such as vehicular accidents and associated injuries, as well as the use of plows to clear roadways.

The study area of Washington, Oregon, and California is characterized by terrain ranging in elevation from sea level along the coast and interior valleys (such as the Central Valley in California), to $\sim 1800 \mathrm{~m}$ north-south oriented coastal mountains, and $\sim 4300-\mathrm{m}$ volcanoes and mountain ranges located farther inland. The cool season is typically humid, rainy, and cold (but above freezing) along the coast from roughly northwestern California north across coastal Washington. Central and southern coastal California is increasingly drier and milder, as are inland valleys. The coastal mountains transition from cool and rainy

${ }^{1}$ Storm data is an officially certified NWS storm dataset that only includes small hail events that produce an impact quantified in dollars, injuries, or fatalitieswhereas local storm reports are not yet certified and may or may not be associated with an impact quantified in dollars. 
to cold and snowy depending on the change in air mass that raises or lowers the freezing level, whereas interior mountains, such as the Cascades and Sierra Nevada, are usually cold enough to support frequent bouts of heavy snow.

The thermodynamic environments of small hail were examined through the use of Rapid Update Cycle (RUC; Benjamin et al. 2004a, 2004b) and Rapid Refresh (RAP; Benjamin et al. 2016) analysis proximity soundings, which were available for events occurring from 2011-2018. Parameters included in the environmental analysis were: surface based convective available potential energy (SBCAPE), SBCAPE within the hail growth zone (HGZ; -10 to $-30^{\circ} \mathrm{C}$ layer); convective inhibition (CIN); the height of the equilibrium level (EL); the wet-bulb zero height (WBZ); the height of the lifted condensation level (LCL); the height of the level of free convection (LFC); precipitable water (PW); the temperature at the equilibrium level (ELT); the temperature at the LCL (LCLT); the temperature and dewpoint at the surface, the temperature at 850,700 , and $500 \mathrm{hPa}$; and the lapse rate in the 950-600-, 850-500-, and 700-500-hPa layer. The authors acknowledge that most unstable and mean layer calculations for parcel-based parameters could yield additional insight into the small hail phenomenon. However, those calculations were not readily available for analysis during the study.

No distance threshold was used to define a proximity sounding. Instead, the closest available RUC or RAP analysis sounding to a small hail event was considered representative if it was located within the same air mass as the small hail shower, which was determined by 1) identifying the location of the sounding with respect to surface features revealed in subjectively analyzed surface charts, and 2) visually inspecting each sounding to ensure thermodynamic and kinematic characteristics were consistent with the surface analyses. In addition to model proximity soundings, monthly synoptic-scale composites of surface and upper-level fields associated with small hail events were generated using the North American Regional Reanalysis (NARR; Mesinger et al. 2006).

Additional analyses were performed using NEXRAD Level-II data so that radar attributes associated with hail showers could be examined. Analyzed radar parameters included: max base reflectivity (BREF), the reflectivity at the $-10^{\circ} \mathrm{C}$ level ${ }^{2}$, vertically integrated liquid (VIL), maximum estimated size of hail (MESH; Witt et al. 1998), cell motion, cell width, cell count within the radar domain, differential reflectivity, correlation coefficient, and specific differential phase. Out of the 880 small hail events identified during the 2008-2018 period, proximity soundings were analyzed for 628 events. In addition, radar data were investigated for 243 out of the 628 sounding events, with $20 \%$ of the 243 sounding/radar events associated with impactful small hail accumulations.

Data were stratified in many different ways, such as time of day, month, hail duration, elevation of occurrence, radar reflectivity, and impacts. For this study, an impactful small hail event was defined as 1) an event that caused a vehicular accident due to accumulations on roadways, or 2) hail accumulated to a depth necessitating clearance by road department plows. The authors acknowledge that a true null (nonimpactful) dataset wasn't obtainable because: 1) biases in reporting may have precluded the inclusion of impacts, 2) not all hail showers occurred over a road or highway, 3) population and vehicular density varied spatially and temporally across the study area, and 4) showers that failed to produce impactful hail were not reported. For those reasons, the non-impactful dataset likely includes events that were potentially impactful if they had occurred at the right time and place. Nevertheless, the results presented hereafter will focus on impacts. Statistically significant differences between impactful and non-impactful events were evaluated using the Mann-Whitney U test (Mann and Whitney 1947). Differences also were determined by visually inspecting box and whisker plots.

Finally, IDSS methods utilized by the NWS in Eureka, California were compiled and summarized. These methods were compared with techniques used by nine other western region NWS offices. Out of the ten-total offices examined, five used enhanced IDSS messaging-strategies when small hail was anticipated. These results will be presented in section 4 .

\section{Results}

\section{a. Spatial and temporal characteristics}

Fifty-two percent of the small hail events in this study occurred in the state of California, 39\% occurred

${ }^{2} \mathrm{The}-10^{\circ} \mathrm{C}$ level was used due to the shallow nature of the convection analyzed. Deeper updrafts typical of the Great Plains of the United States would have justified analyzing reflectivity at the $-20^{\circ} \mathrm{C}$ level as well. 


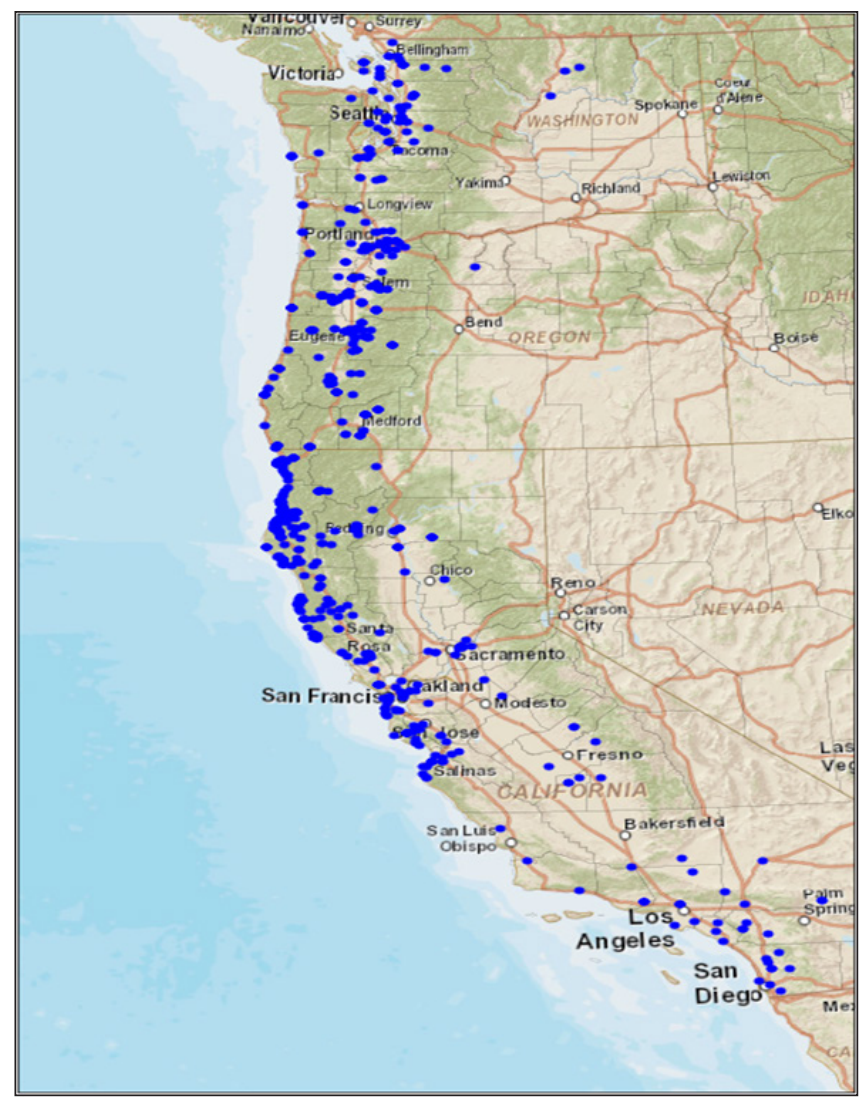

Figure 1. Geographic location of west coast small hail reports (blue dots) examined from 2008-2018. Click image for an external version; this applies to all figures hereafter.

in Oregon, and 9\% were from Washington (Fig. 1). Reports were regionally clustered near population centers, possibly due to reporting bias, which included the Seattle/Tacoma metro area, the Interstate 5 corridor between Portland, Oregon and Eugene, Oregon, the Highway 101 corridor from Crescent City, California south through Eureka, California and farther south across the San Francisco Bay Area, and finally the Los Angeles, San Diego, and Sacramento metro areas.

Eighty percent of the small hail events occurred from December to April (defined hereafter as the cool season), with the greatest number of monthly reports (220) occurring during the month of March (Table 1 and Fig. 2). Reanalysis composite charts, such as those created for the month of March, show these cool season hail events were associated with an amplified 700300-hPa trough positioned from the southern coast of British Colombia south across the coast of Washington, Oregon, and northern California, similar to the 500$\mathrm{hPa}$ trough shown in Fig. 3. Furthermore, a very cold midlevel air mass was collocated with the trough (Fig.

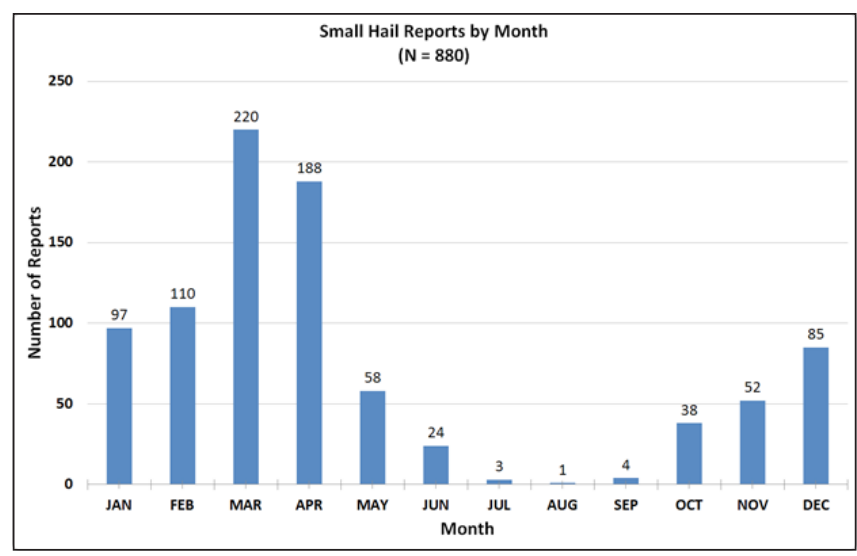

Figure 2. Distribution of small hail reports examined by month from 2008-2018.

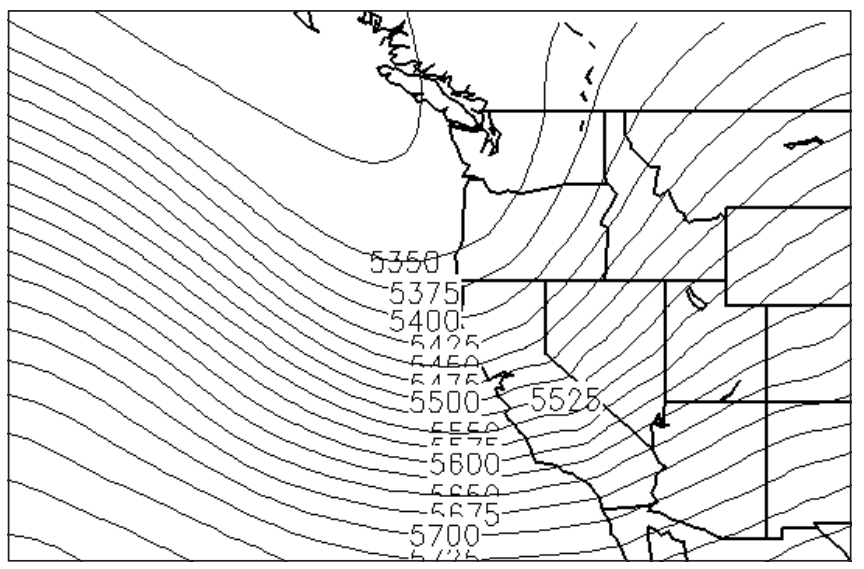

Figure 3. Mean 500-hPa geopotential height (meters) for small hail events examined during the month of March 2008-2018. Data source is the North American Regional Reanalysis.

4), with the coldest temperatures observed during the months of maximum small hail occurrence (see Fig. 5 for average monthly upper-air temperatures associated with small hail).

The diurnal frequency of small hail generally followed the solar cycle, with reports peaking during the afternoon, followed by a minimum in reports during the early morning (see Table 2 and Fig. 6). The nocturnal minimum may partly be a function of fewer people available to observe small hail because they were asleep. Similarly, fewer drivers would be expected on the road late at night, which explains why accidents peaked during mid-morning through early evening (1600-0359 UTC) and fell to a minimum during the early morning period (0800-1159 UTC).

Small hail reports were frequently clustered along major travel corridors. For instance, Fig. 7 shows U.S. 
Table 1. Monthly distribution and percentage total of small hail reports, accidents attributed to small hail accumulations, and vehicles involved in an accident.

\begin{tabular}{|l|l|l|l|}
\hline Month & Events & Accidents & Vehicles Involved \\
\hline January & $97(11 \%)$ & $10(20 \%)$ & 31 (3.1/accident) \\
\hline February & $110(13 \%)$ & $8(16 \%)$ & 38 (4.8/accident) \\
\hline March & $220(25 \%)$ & $13(27 \%)$ & 26 (2/accident) \\
\hline April & $188(21 \%)$ & $5(10 \%)$ & 24 (4.8/accident) \\
\hline May-September & $90(10 \%)$ & $1(2 \%)$ & 1 (1/accident) \\
\hline October & $38(4 \%)$ & $1(2 \%)$ & 2 (2/accident) \\
\hline November & $52(6 \%)$ & $0(0 \%)$ & 0 (0/accident) \\
\hline December & $85(10 \%)$ & $17(23 \%)$ & 17 (1.5/accident) \\
\hline
\end{tabular}

Table 2. Temporal distribution and percentage total of small hail reports, accidents attributed to small hail accumulations, and vehicles and injuries per accident. Mid-morning begins at roughly 1600 UTC (0800/0900 PST/ PDT), with evening beginning at approximately 0000 UTC (1600/1700 PST/PDT). Early morning occurs between 0800 and 1159 UTC (0000/0100-0359/0459 PST/PDT).

\begin{tabular}{|l|l|l|l|l|}
\hline Time (UTC) & Small Hail Reports & Accidents & $\begin{array}{l}\text { Vehicles per } \\
\text { Accident }\end{array}$ & $\begin{array}{l}\text { Injuries per } \\
\text { Accident }\end{array}$ \\
\hline $0000-0359$ & $182(21 \%)$ & $11(22 \%)$ & 5.3 & 2.2 \\
\hline $0400-0759$ & $49(5 \%)$ & $6(12 \%)$ & 2.3 & 0.3 \\
\hline $0800-1159$ & $25(3 \%)$ & $3(6 \%)$ & 1.3 & 0 \\
\hline $1200-1559$ & $59(7 \%)$ & $4(8 \%)$ & 3.3 & 0.3 \\
\hline $1600-1959$ & $212(24 \%)$ & $13(27 \%)$ & 1.8 & 0.3 \\
\hline $2000-2359$ & $353(40 \%)$ & $12(25 \%)$ & 2.3 & 0.8 \\
\hline
\end{tabular}

Highway 101 running north to south through Eureka, California. Seventy-nine hail reports are located within the figure, with $58 \%$ occurring on the highway. In addition, small hail was more likely to be observed at elevations $\leq 305$-m MSL (hereafter defined as lowelevation), at a ratio of roughly 3.4 low-elevation reports for every high-elevation report. Low-elevation reports may have been more frequent because human observers typically reside in lower elevations. Likewise, a majority (77\%) of small hail related vehicular accidents occurred at low-elevations, again most likely due to more car drivers located at low elevations. The authors speculate that the higher concentration of people at low elevations, combined with an expectation that icecovered roads are confined to high elevations, may have contributed to the greater number of low-elevation accidents. This is a topic worthy of additional research and could serve as a point of emphasis when providing IDSS to NWS partners and the public.

\section{b. Environments}

Bulk radar characteristics from 243 small hail showers occurring between 2008 and 2018 displayed average max-BREF values near $48 \mathrm{dBZ}$ during the time of small hail occurrence, with a range from 29 to 69 $\mathrm{dBZ}$, and a standard deviation of $4.6 \mathrm{dBZ}$. Despite this range, the statistical correlation was very low (not shown) between max-BREF and impactful small hail accumulations, though admittedly the sample size of impactful events was small ( $20 \%$ out of 243 events). The average max reflectivity value at the base of the hail growth zone (the $-10^{\circ} \mathrm{C}$ level) was $37 \mathrm{dBZ}$ for all hail showers studied, which was slightly less than the 40-dBZ threshold considered by Kalina et al. (2016) to be associated with the presence of graupel within a convective cell. Other variables, such as the polarimetric radar variable differential reflectivity (ZDR) averaged $0.1 \mathrm{~dB}$ for impactful small hail events, and $0.3 \mathrm{~dB}$ for non-impactful events. These weakly positive values of ZDR are consistent with values expected for small hail 


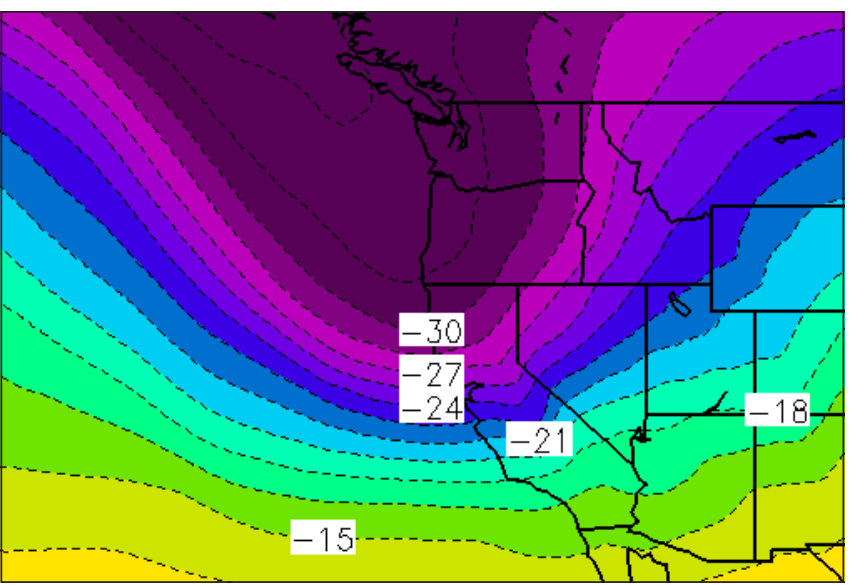

Figure 4. Same as in Fig. 3, except for temperature $\left({ }^{\circ} \mathrm{C}\right)$.

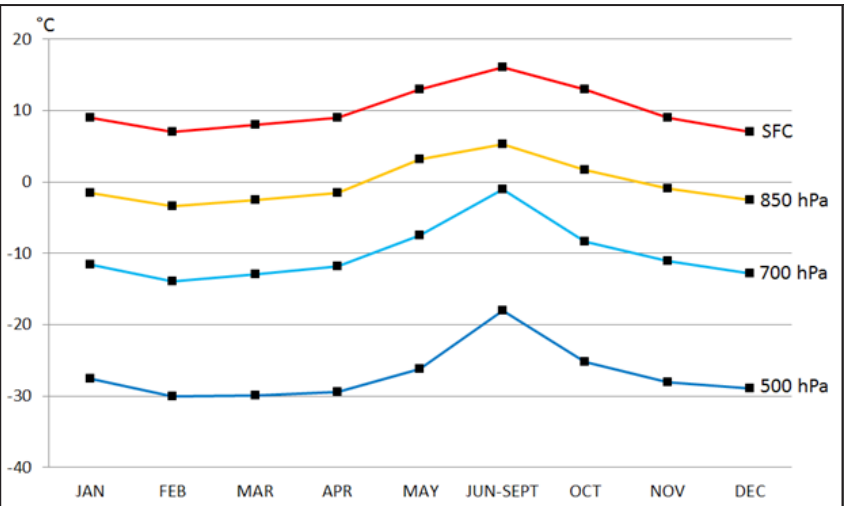

Figure 5. Monthly mean temperatures $\left({ }^{\circ} \mathrm{C}\right)$ for small hail events for the surface, 850-, 700-, and 500-hPa level.

and graupel.

The median radar derived echo top was around $4200 \mathrm{~m}$. In addition, the average cell width was 3.3 $\mathrm{km}$, which is only $18 \%$ of the diameter of a typical thunderstorm cell (on the order of $18.5 \mathrm{~km}$; Orlanski 1975). The diameter of each hail shower was combined with its speed (averaging $10.7 \mathrm{~m} \mathrm{~s}^{-1}$ ), which yielded a point-average hail duration of $5.1 \mathrm{~min}$. In addition, if other cells were occurring within the radar domain, and they displayed reflectivity signatures similar to a verified hail shower, they were included in a cell count. Based on that count, if one hail shower was ongoing, an average of 17 other hail showers were occurring at the same time. Otherwise, statistical correlation coefficients and visual inspection of box and whisker plots (not shown) indicated that traditional radar hail guidance, such as VIL and MESH, provided little if any ability in discriminating between impactful versus

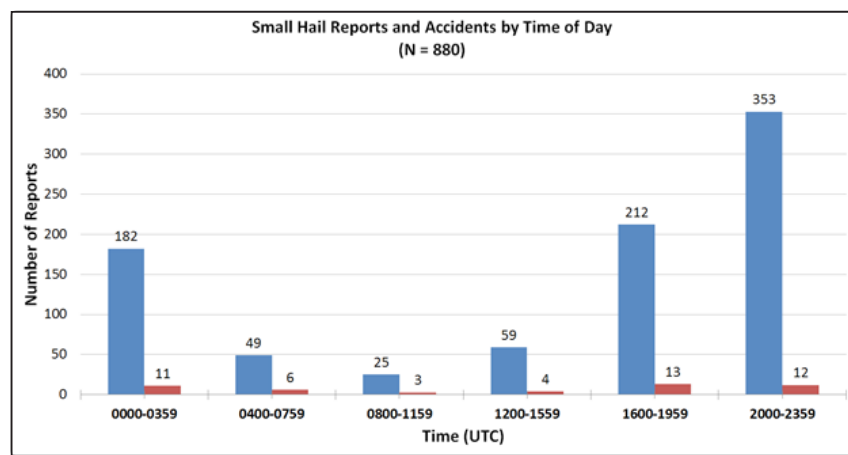

Figure 6. Same as in Fig. 2, except for small hail reports and accidents by time of day. Blue bars are total number of hail reports, and red bars are total number of accidents. Mid-morning begins at roughly 1600 UTC (0800/0900 PST/PDT), with evening beginning at approximately 0000 UTC (1600/1700 PST/PDT). Early morning occurs between 0800 and 1159 UTC (0000/0100-0359/0459 PST/PDT).

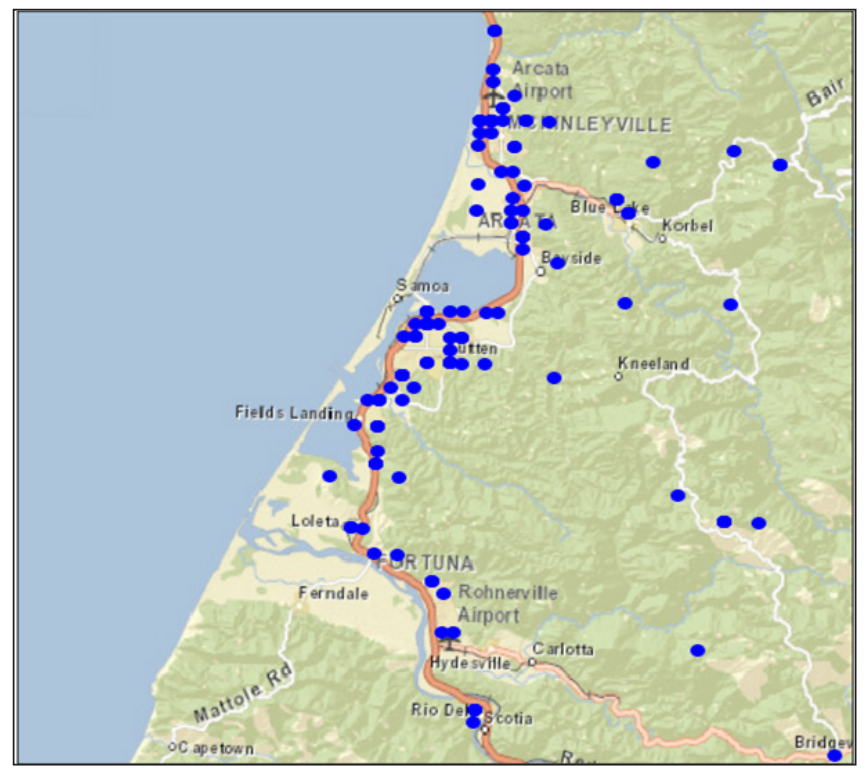

Figure 7. Same as in Fig. 1, except for small hail report locations occurring in the vicinity of Eureka, California. Highway 101 is the bold orange line running from the top to bottom of the figure.

non-impactful hail accumulations. In addition, hail showers displayed an assortment of convective modes, ranging from isolated discrete cells, clusters of cells, and broken lines of cells (see Figs. 8 and 9 for typical radar presentations).

The cold upper trough that provides an ambient environment favorable for small hail showers also produces conditions supportive of mountain snow, heavy rain, flooding, and strong winds. Out of 880 
Table 3. Mean, median, minimum ( $\mathrm{min})$, 25th percentile, 75th percentile, maximum (max), and standard deviation (STDEV) for model sounding parameters. Units: SBCAPE and HGZ CAPE in $\mathrm{J} \mathrm{kg}^{-1}$; EQLVL and WBZ in $\mathrm{m}$; PW in cm; LCLt, ELt, SFCT, SFCTd, 850T, 700T, and 500T in ${ }^{\circ} \mathrm{C}$; 950-600-hPa lapse rate in ${ }^{\circ} \mathrm{C} \mathrm{km}^{-1}$.

\begin{tabular}{|c|c|c|c|c|c|c|c|c|c|c|c|c|c|}
\hline & SBCAPE & $\begin{array}{c}\text { HGZ } \\
\text { CAPE }\end{array}$ & $\begin{array}{l}\text { EQ- } \\
\text { LVL }\end{array}$ & WBZ & PW & $\mathbf{L C L}_{\mathrm{T}}$ & $\overline{E \mathbf{L}_{\mathrm{T}}}$ & $\mathrm{SFC}_{\mathrm{T}}$ & $\overline{\mathrm{SFC}_{\mathrm{Td}}}$ & \begin{tabular}{|l|l}
$8^{250}$ \\
\end{tabular} & $700_{\mathrm{T}}$ & $5 \mathbf{5 0 0}_{\mathrm{T}}$ & $\begin{array}{c}\text { 950-600-hPa } \\
\text { Lapse Rate }\end{array}$ \\
\hline Mean & 132 & 61 & 4643 & 1031 & 1.3 & 4.2 & -25 & 8.7 & 4.8 & -1.5 & -11.8 & -29 & 7.0 \\
\hline Median & 95 & 37 & 4656 & 981 & 1.2 & 4.0 & -24 & 8.6 & 5.0 & -2.0 & -12.0 & -29 & 7.1 \\
\hline Min & 1 & 0 & 152 & 0 & 0.5 & -11.1 & -56 & -3.8 & -4.9 & -9.0 & -20.0 & -44.0 & 3.1 \\
\hline 25th Percentile & 40 & 6 & 3417 & 744 & 1.0 & 2.2 & -35 & 6.6 & 2.8 & -4.0 & -14.0 & -32 & 6.6 \\
\hline 75th Percentile & 180 & 90 & 5912 & 1240 & 1.4 & 6.2 & -16 & 10.4 & 6.7 & 0.0 & -10.0 & -26 & 7.4 \\
\hline Max & 1139 & 558 & 10813 & 3789 & 3.3 & 17.0 & 31.5 & 26.9 & 14.7 & 21.3 & 8 & -10 & 10.5 \\
\hline STDEV & 135 & 72 & 1702 & 443 & 0.4 & 3.4 & 12.5 & 3.3 & 3.0 & 3.5 & 3.8 & 4.7 & 0.8 \\
\hline
\end{tabular}

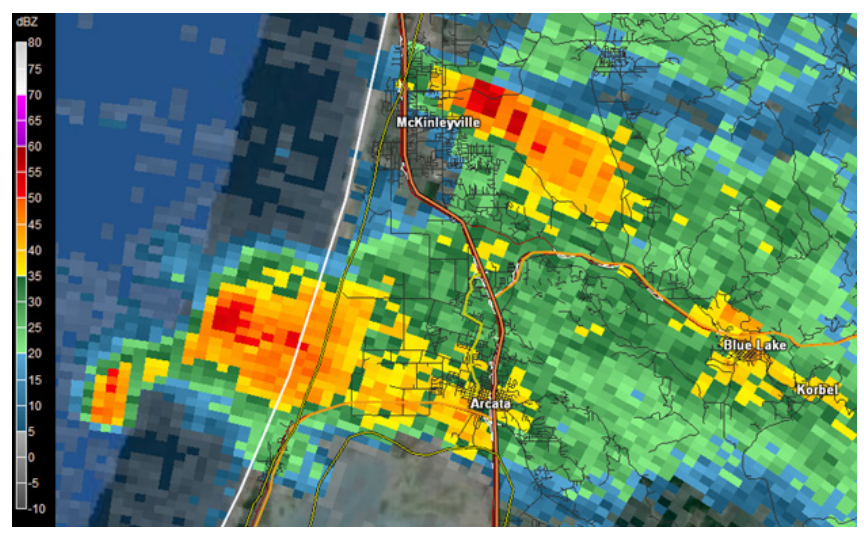

Figure 8. Typical plan-view base reflectivity radar presentation for west coast hail showers, valid 1954 UTC 10 December 2015.

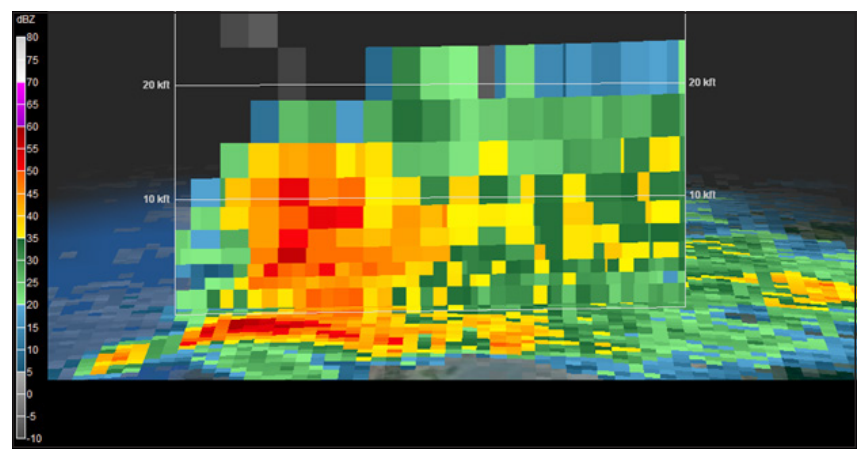

Figure 9. Same as in Fig 8, except for vertical cross section. Vertical units are in thousands of feet $(\mathrm{kft})$.

small hail reports, 299 (34\%) were part of a multihazard event within the NWS county warning area of their occurrence, and of those 299 reports, 191 $(64 \%)$ occurred in tandem with heavy snow over the mountains.

The upper-level air mass for all events studied was characterized by average midlevel temperatures

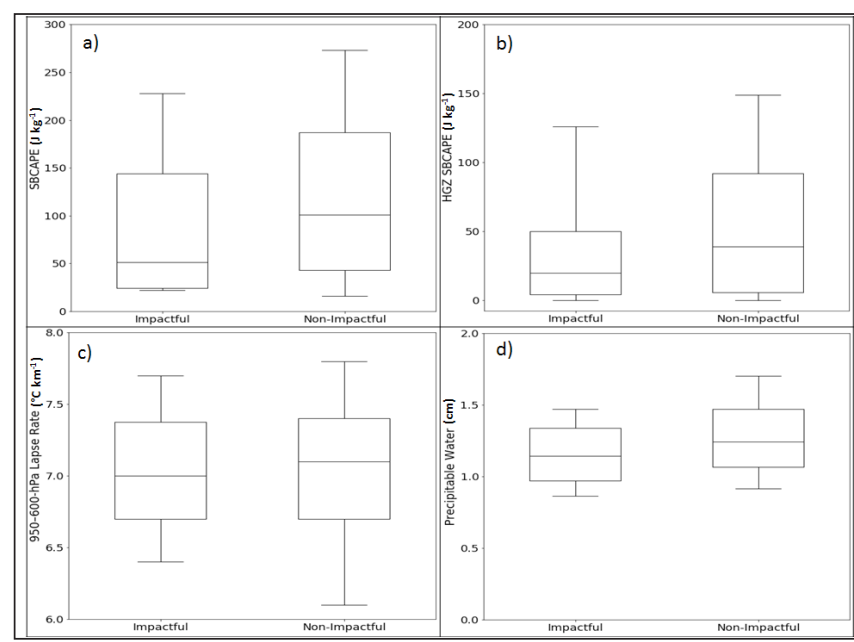

Figure 10. Box and whisker plots comparing impactful versus non-impactful small hail events. The boxed region represents the inter-quartile range, divided at the median. Whiskers represent the 10th and 90th percentiles. Parameters presented include a) SBCAPE $\left.\left(\mathrm{J} \mathrm{kg}^{-1}\right), \mathrm{b}\right) \mathrm{SBCAPE}$ in the hail growth zone (HGZ CAPE; $\left.\mathrm{J} \mathrm{kg}^{-1}\right)$, c) the $950-600-\mathrm{hPa}$ lapse rate $\left({ }^{\circ} \mathrm{C} \mathrm{km}^{-1}\right)$, and $\mathrm{d})$ precipitable water $(\mathrm{cm})$.

of $-29^{\circ} \mathrm{C}$ at $500 \mathrm{hPa},-12^{\circ} \mathrm{C}$ at $700 \mathrm{hPa}$, and $-1.5^{\circ} \mathrm{C}$ at $850 \mathrm{hPa}$ (Table 3). The mean temperatures identified at 500 and $700 \mathrm{hPa}$ reside at or below the 10th percentile for the midlatitude west coast cool season air mass observed at Medford, Oregon using climatological upper-air data from the Storm Prediction Center (www. spc.noaa.gov/exper/soundingclimo/). Furthermore, a two-tailed Mann-Whitney statistical significance test at $\alpha=0.01$ shows that the difference in medians between impactful versus non-impactful events was statistically significant for 850 - and 700 -hPa temperatures. Further investigation using box and whisker plots (Figs. 10 and 


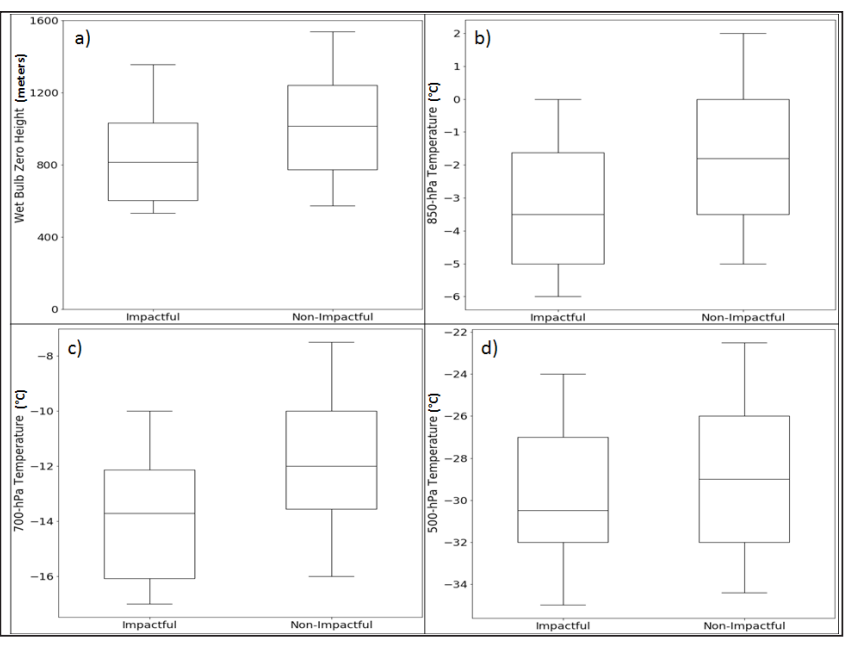

Figure 11. Same as in Fig. 10, except for a) wet bulb zero height (meters), b) $850-\mathrm{hPa}$ temperature $\left({ }^{\circ} \mathrm{C}\right)$, c) 700-hPa temperature $\left({ }^{\circ} \mathrm{C}\right)$, and d) $500-\mathrm{hPa}$ temperature $\left({ }^{\circ} \mathrm{C}\right)$.

11) reveals that $850-\mathrm{hPa}$ temperatures colder than -2 or $-3^{\circ} \mathrm{C}$ delineate an increasingly favorable environment for impactful small hail events, and the same was true at $700 \mathrm{hPa}$ when temperatures were colder than roughly -12 to $-13^{\circ} \mathrm{C}$.

Surface conditions supportive of small hail accumulating on the ground were associated with an average temperature and dewpoint of $8.7^{\circ} \mathrm{C}$ and $4.8^{\circ} \mathrm{C}$, respectively. But perhaps more importantly, impactful small hail accumulations were more likely when surface temperatures were $\leq 8^{\circ} \mathrm{C}$, while non-impactful events were more likely above $8^{\circ} \mathrm{C}$ (Fig. 12). The colder surface temperatures observed for impactful events may signal an environment that inhibits rapid melting of small hail and graupel on the ground, which would subsequently favor greater accumulations on roadways.

An unstable marine layer combined with the lack of an elevated mixed layer (Carlson et al. 1983) precluded large values of CIN (average values for all hail events were around $9 \mathrm{~J} \mathrm{~kg}^{-1}$ ). In addition, the cool surface conditions likely inhibited the generation of large SBCAPE (values averaged around $132 \mathrm{~J} \mathrm{~kg}^{-1}$ for all hail events studied), and also promoted a low EL height (4643 m). Furthermore, when impactful versus nonimpactful events were compared, the median SBCAPE was $\sim 50 \mathrm{~J} \mathrm{~kg}^{-1}$ lower for the impactful events (see Fig. 10). The authors speculate that SBCAPE was lower for impactful events due to a colder environment, which is evident in the box and whisker plots presented in Figs. 11 and 12. This result demonstrates that SBCAPE is not of primary importance in the generation of impactful

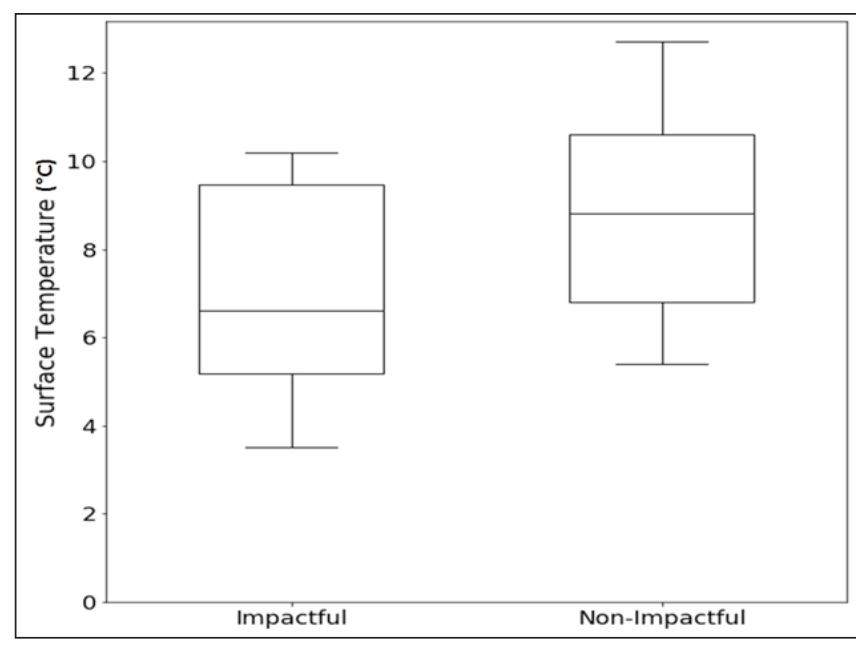

Figure 12. Same as in Fig. 10, but for surface temperature $\left({ }^{\circ} \mathrm{C}\right)$.

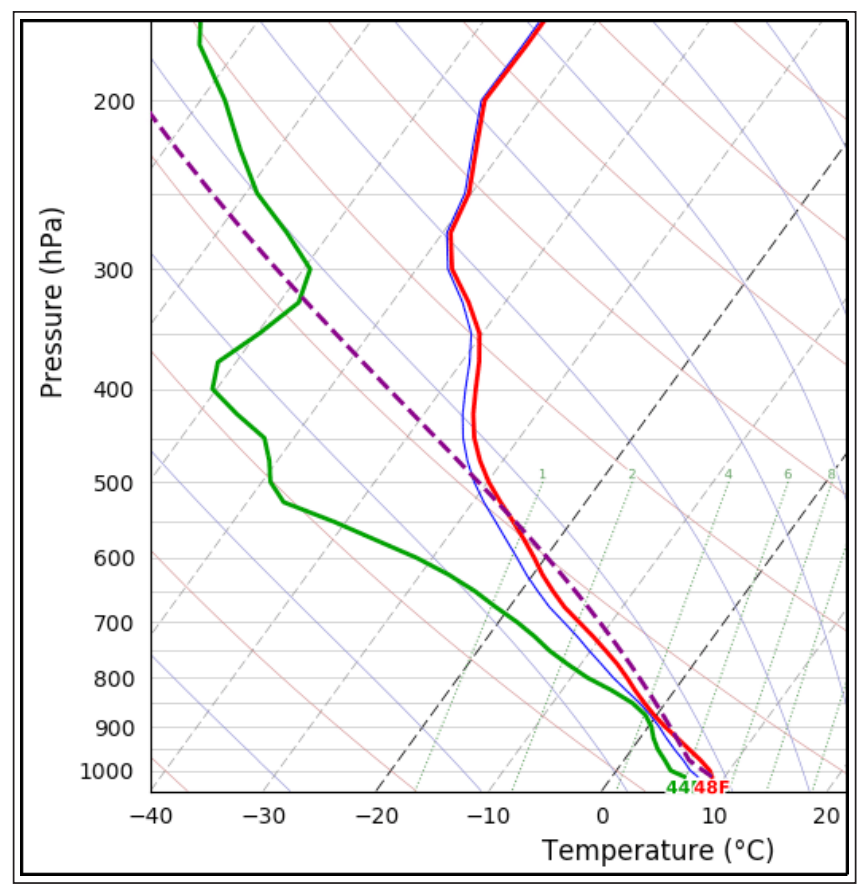

Figure 13. Typical small hail model proximity sounding valid 01 UTC 26 January 2018 at Eureka, California. The red line is the environmental temperature curve, the green line is the environmental dewpoint curve, and the dashed line is the surface based parcel trace.

small hail accumulations during the West Coast cool season - but instead it is the very cold environment that aids in the generation of large numbers of ice particles by weak convective showers. Nevertheless, lightning was occasionally observed with small hail showers when SBCAPE was sufficiently large (approximately greater than $\left.100 \mathrm{~J} \mathrm{~kg}^{-1}\right)$, the LCLT was warm $\left(>-10^{\circ} \mathrm{C}\right)$, 


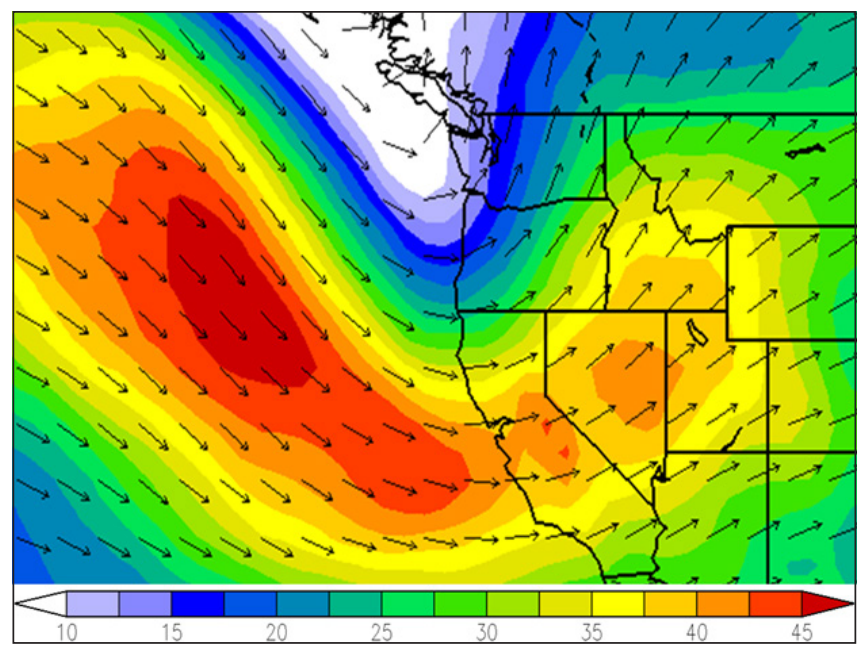

Figure 14. Same as in Fig. 3, except for $300-\mathrm{hPa}$ windspeed $\left(\mathrm{m} \mathrm{s}^{-1}\right)$ and direction.

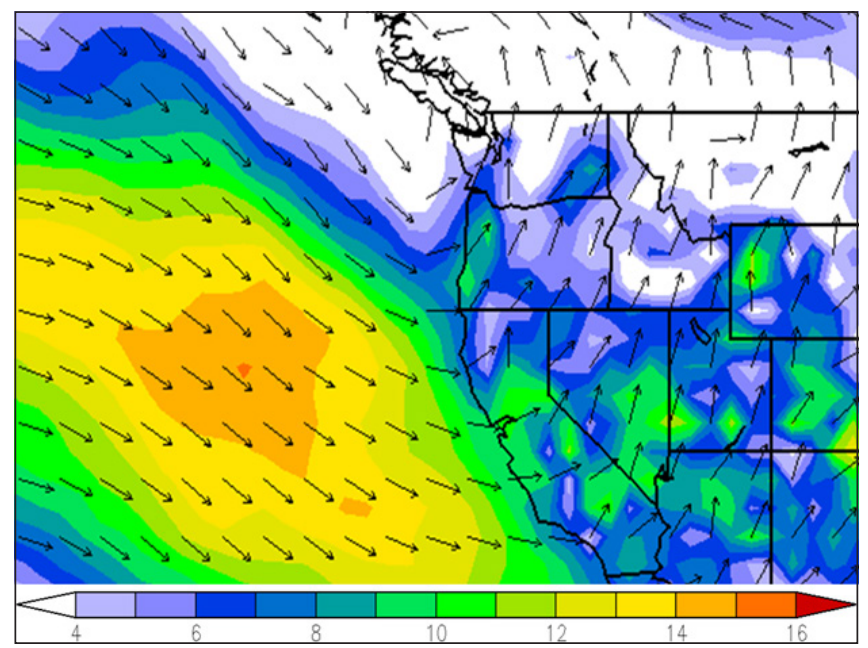

Figure 15. Same as in Fig. 14, except for $850 \mathrm{hPa}$.

and the ELT was $\leq-20^{\circ} \mathrm{C}$ (Bright et al. 2005). Reference Fig. 13 for a typical small hail sounding that was also associated with lightning.

The WBZ level has been used by severe weather forecasters to anticipate the degree of melting potential as hail falls to the surface. A study by Edwards and Thompson (1998) found that marginally severe hail with diameters between 19 and $25 \mathrm{~mm}$ occurred with WBZ levels ranging from $\sim 1250$ to $4500 \mathrm{~m}$. Small hail events in the current study, whose diameters were $\leq 19$ $\mathrm{mm}$, displayed a WBZ inter-quartile range from 744 to $1240 \mathrm{~m}$, which indicates that small hail environments are associated with lower hailstone melting potential compared to marginally severe hail environments. This was particularly true in the current study for events that caused accidents, where the median value was $\sim 800 \mathrm{~m}$, which was nearly $300 \mathrm{~m}$ lower than the median value for events that did not cause accidents. In addition, small hail environments were found to have lower hail growth potential. For example, Johnson and Sugden (2014) found that the 10th percentile of CAPE in the hail growth zone for marginally severe hail environments was $230 \mathrm{~J} \mathrm{~kg}^{-1}$, which is $81 \mathrm{~J} \mathrm{~kg}^{-1}$ larger than the 90th percentile found in the current study.

Deep-layer westerly winds from $850 \mathrm{hPa}$ to 300 $\mathrm{hPa}$ typified the synoptic-scale flow regime in the NARR for most small hail events examined across the west coast (Figs. 14 and 15). The westerly flow aided in orographic augmentation to the convective environment as it forced cells to move onshore, at which point they encountered steep mountainous terrain. As cells moved from water to land, they experienced an average increase in reflectivity of $+17 \%$, possibly due to frictional convergence, sea-breeze circulations, or daytime surface heating along the coast. Furthermore, when cells encountered the windward side of mountains and ridges, the average change in reflectivity was $+47 \%$. Although not confirmed, it is hypothesized that the observed increase in reflectivity signals enhanced hail production, which would be consistent with the results of Kalina et al. (2016).

\section{c. Small hail parameter}

A small hail parameter was developed at NWS Eureka using the results presented in this paper, and has been coded into the Advanced Weather Interactive Processing System version 2 (AWIPS II) Graphical Forecast Editor (GFE). The parameter can be computed using all existing model data within GFE, with output displayed in plan-view, at which point forecasters can integrate the temporal and spatial details in the small hail guidance into their forecast products and disseminate the information to partners and the public.

The components of the parameter include SBCAPE, hail melting potential, and the deep-layer temperature profile. Each component has been normalized by subjectively inferring approximate threshold values via visual inspection of box and whisker plots (see Figs. 10 and 11) that compare impactful versus non-impactful small hail events. The compositing of individual parameters into a tool used to anticipate small hail is similar to the development of other parameters highlighting supercell and tornado environments (Thompson et al. 2003). 


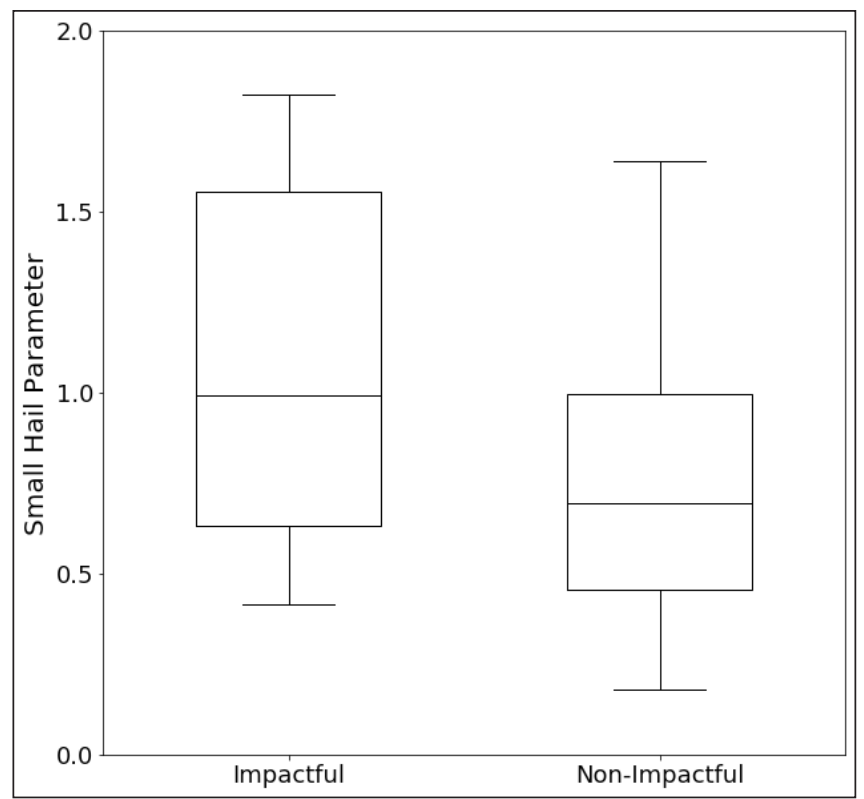

Figure 16. Same as in Fig. 10, but for the small hail parameter (dimensionless).

Small Hail Parameter $=\left[\frac{\mathrm{SBCAPE}}{30 \mathrm{Jkg}^{-1}} \times \frac{800 \mathrm{~m}}{\mathrm{WBZ}} \times \frac{850 \mathrm{~T}+700 \mathrm{~T}+500 \mathrm{~T}}{-46^{\circ} \mathrm{C}}\right]$ $\left\{\right.$ if SBCAPE $\geq 30 \mathrm{~J} \mathrm{~kg}^{-1}$, then $\frac{\mathrm{SBCAPE}}{30 \mathrm{Jkg}^{-1}}=1$,

where SBCAPE is the surface-based CAPE, WBZ is the wet-bulb zero height, and $850 \mathrm{~T}, 700 \mathrm{~T}$, and 500T are the temperatures at 850,700 , and $500 \mathrm{hPa}$, respectively. The box and whisker plots presented in Fig. 10 indicate that impactful small hail events were more likely to occur with SBCAPE values that were lower when compared to non-impactful events. Nevertheless, SBCAPE was still included in the small hail parameter, because some amount of CAPE was necessary to ensure sufficient shower-updraft strength would be present for graupel and small hail growth. However, in order to acknowledge that high values of CAPE are not necessary for impactful small hail, the SBCAPE contribution to the small hail parameter was limited to 1.0 when SBCAPE was $\geq 30 \mathrm{~J} \mathrm{~kg}^{-1}$. This yielded an average small hail parameter of 1.1 for impactful events, and 0.8 for non-impactful events. The Mann-Whitney U-test reveals that statistically significant differences exist between impactful and non-impactful small hail parameter values, and box and whisker plots show that the upper half of the impactful sample is located above 1.0, whereas the lower three-quarters of the nonimpactful events reside below 1.0 (Fig. 16).

Hypothetically, showers embedded within an environment where the small hail parameter is $\geq 1$ will possess sufficient updraft strength for hail/graupel

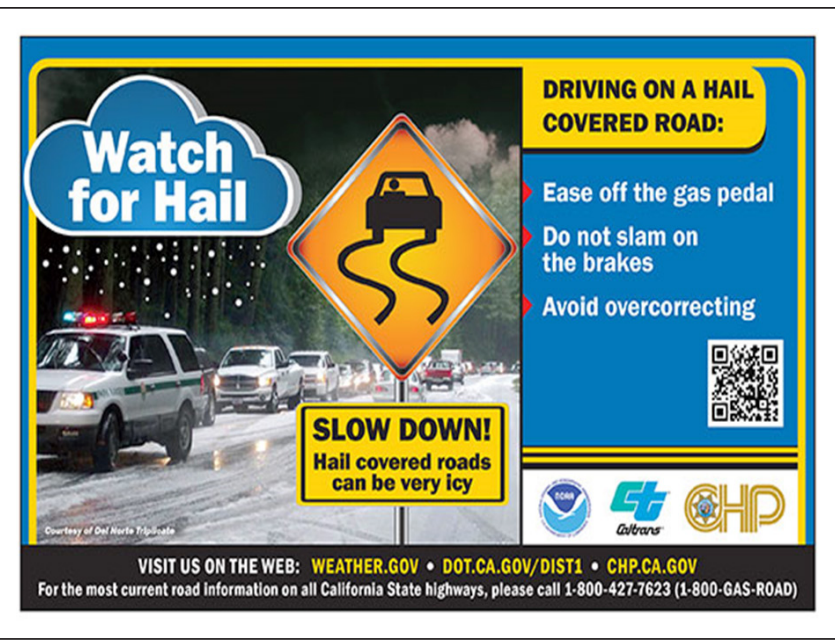

Figure 17. Poster created by NWS Eureka, California, Caltrans District 1, and the California Highway Patrol highlighting the driving hazards associated with small hail.

production amidst a deep-layer temperature profile that will be cold enough to support the development of large numbers of ice particles that would not be subjected to excessive melting during descent.

\section{Impact-Based Decision Support}

\section{a. Public education}

"Driving on a hail-covered road is very similar to driving on a sheet of ice." That was the message conveyed in local newspapers (Redwood Times, cited 2018) by NWS Eureka, Caltrans District 1, and the California Highway Patrol during the 2012 "Watch for Hail" campaign. The campaign was used to educate the public on the hazards of accumulating small hail by emphasizing: 1) dark clouds ahead may signal the potential for hail, 2) motorists should slow down if small hail is observed, 3) drivers should turn on headlights, 4) turn off cruise control, and 5) motorists shouldn't panic if their car begins to slide on hail covered roadways, because sudden braking and steering adjustments can result in loss of vehicle control. Some of these safety bullets were summarized in a poster (Fig. 17) that continues to be disseminated by NWS Eureka and their partners, both online and at various physical locations throughout northwestern California. Although not immediately quantifiable, it is believed that this public education effort laid the foundation for more accurate perceptions and expectations with regard to ice-covered low-elevation roads, which in turn would 


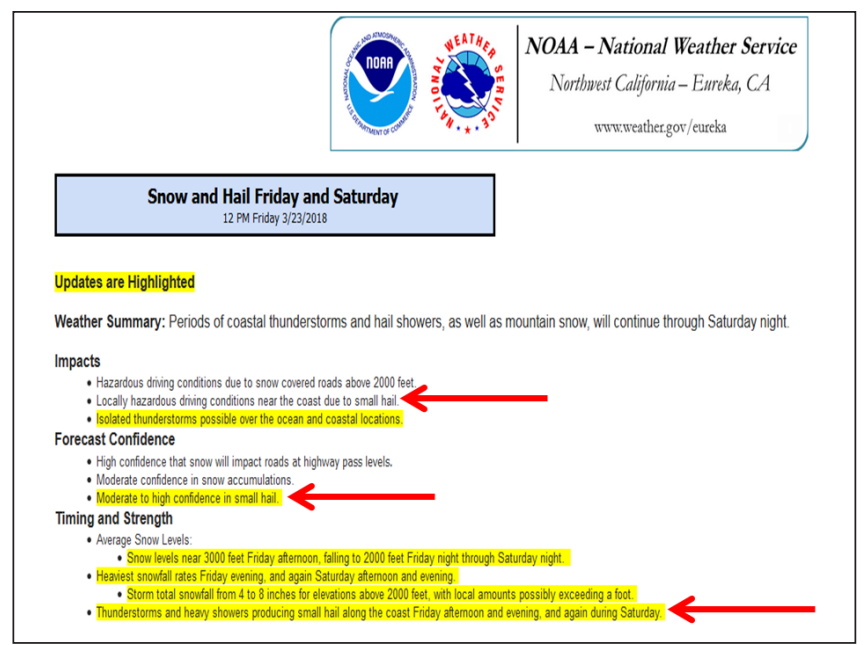

Figure 18. Example of an NWS partner email detailing the impacts, forecast confidence, timing, and strength of an impending small hail event. Items related to small hail are annotated by red arrows.

foster an appropriate public response when small hail is encountered.

\section{b. Messaging}

West coast NWS offices have implemented messaging strategies that address accumulating small hail threats through a combination of long-fused outlooks followed by short-term techniques that add increasing detail in the timing of small hail, as well as its location of occurrence and impact on the public. The outlook stage is handled through products such as the Hazardous Weather Outlook, Area Forecast Discussion, and gridded forecasts. In addition, several NWS offices compose and disseminate emails to their local and regional government partners highlighting the small hail threat, the expected impacts, and forecaster confidence (Fig. 18). Public-friendly weather stories highlighting the "who, what, where, and when" of an impactful hail event also were developed by forecasters for Facebook and Twitter. These weather stories are used to emphasize the potential for icy low-elevation roads, and also provide safe-travel best practices. In addition, the Flagstaff, Arizona NWS office augmented their social media posts by specifically identifying mile-markers or other landmarks that aided the public in identifying where current travel conditions were most severe.

A novel forecast strategy was tested by NWS Eureka during the winter of 2018. The office began exploring the issuance of winter weather advisories for small hail occurring along the coast of northwestern California.

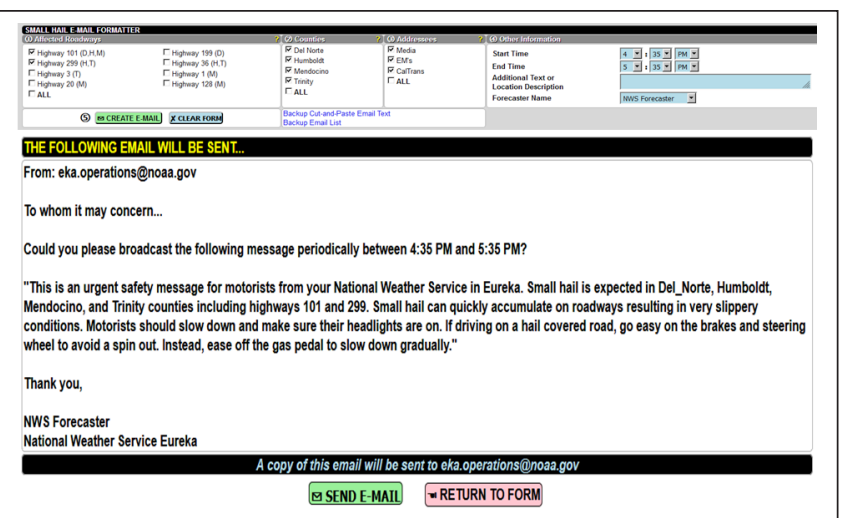

Figure 19. Example of the NWS Eureka, California, GUI used to generate a small hail message for dissemination to regional radio stations and road departments.

Traditionally, winter weather advisories have been reserved for sub-warning level snowfall, blowing snow, or sleet that creates a nuisance for the public. However, accumulating small hail produces similar impacts, especially near sea level due to previously discussed public perceptions. The effectiveness of small hail winter weather advisories is not completely known at this time, but NWS Eureka plans to continue testing the advisories during future cool seasons.

When small hail appeared imminent based on radar, satellite, short-term model guidance, or information received from spotters and the public, NWS offices amplified their messaging through nowcasts, Special Weather Statements, and continued social media posts. In addition, forecasters at NWS Eureka produced a preformatted small hail email that was sent to regional radio stations and road departments (Fig. 19). The radio stations relayed the on-air message periodically to the public during a time frame determined by the forecaster, which warned motorists about possible hail-covered roads, while also giving a set of recommended actions for motorists to take if hail was encountered while driving. Several NWS offices, including NWS Eureka, also contact their regional transportation departments during small hail episodes, who often post small hail alerts on their electronic highway message boards.

\section{Summary and Discussion}

The environments and hazards of cool season small hail occurring across the west coast of the United States have been examined. Small hail events increased in frequency during December, peaked in March, and quickly fell off in occurrence during May. Small hail 
accumulating across low elevations often occurs in conjunction with heavy mountain snow as numerous showers develop within a cold upper-level trough that slowly progresses eastward across the west coast. It appears that very little SBCAPE, perhaps only slightly greater than $0 \mathrm{~J} \mathrm{~kg}^{-1}$, is necessary for the production of large amounts of ice particles when very cold midlevel temperatures are present. Such meager values of CAPE would result in short hail-embryo residence times within the hail growth zone, which limits hailstone diameters. Furthermore, supercooled liquid water was inferred to be low within the updraft of hail showers analyzed. Nevertheless, research by Takahashi et al. (Takahashi 1993, Takahashi et al. 1995) shows that high ice crystal concentrations, which would favor large amounts of accumulating small hail or graupel, can occur in wintertime maritime cumulus clouds when cold deep-layer temperatures, around $-16^{\circ} \mathrm{C}$, are collocated with low CAPE environments and marginal supercooled liquid water content. Temperatures near $-16^{\circ} \mathrm{C}$ generally occur between the 700- and 500$\mathrm{hPa}$ level, and when that air mass is positioned above surface temperatures $\leq 8^{\circ} \mathrm{C}$, the potential for impactful small hail accumulations was found to be enhanced.

A small hail composite parameter has been introduced. This parameter signals an increasingly favorable environment for impactful small hail when values are $\geq 1.0$ due to a combination of sufficient updraft strength for hail growth, lower hail melting potential, and a cold environment favorable for the production of large numbers of ice particles. The small hail parameter is used operationally within the AWIPS II GFE at NWS Eureka, which allows forecasters to assess the temporal and spatial characteristics of the small hail threat out to seven days, and subsequently employ that information toward public and partner messaging.

The authors partially identified impactful versus non-impactful hail events, although a true null dataset wasn't obtainable because: 1) biases in reporting may have precluded the inclusion of impacts, 2) not all hail showers occurred over a road or highway, 3) population and vehicular density varied spatially and temporally across the study area, 4) showers that failed to produce hail were not reported, and 5) even those hail showers that displayed weak radar signatures occurred within an environment that was statistically similar to strong radar signature showers. However, the authors speculate that the probability of an impactful event most likely increases when showers occurring within a marginally unstable and very cold deep-layer air mass fortuitously overlap a busy travel corridor. Impactful hail-falls may also be enhanced as shower-updrafts are strengthened when they abruptly encounter steep terrain. In addition, travel hazards may be augmented when motorists quickly transit from rain covered roads to hail covered, with the threat maximized during the peak in motorvehicle activity from late morning through early evening. During those situations, messaging could be enhanced by NWS offices and their partners through a combination of social media outreach, partner emails, radio broadcasts, highway message boards, and traditional forecast products such as the Hazardous Weather Outlook, nowcasts, and Special Weather Statement. Future events may also be highlighted in winter weather advisories - an NWS product that has traditionally been used for nuisance snow events.

This research speculates on perceptions, expectations, and decision-making by the public when hail-covered roadways are encountered at low elevations. Quantifying those attributes through surveys or other social science methods would yield valuable insight specifically into the west coast small hail hazard, and more generally into the behavior of humans when they are confronted with unusual weather scenarios. Those insights, combined with the meteorological analysis presented in this paper, would provide forecasters with a more complete set of tools they could leverage in educating and warning the public, as well as supporting their core government partners.

Acknowledgments: The authors thank the management and staff at the National Weather Service Forecast Office in Eureka, California, as well as the National Weather Service Western Region Headquarters for supporting this research project. The authors also thank the NWA editorial team as well as three anonymous reviewers for their beneficial comments and suggestions.

\section{REFERENCES}

Ashley, W. S., S. Strader, D. Dziubla, and A. Haberlie, 2015: Driving blind: Weather-related vision hazards and fatal motor vehicle crashes. Bull. Amer. Meteor. Soc., 96, 755-778, CrossRef. 
Becker, J. S., H. L. Taylor, B. J. Doody, K. C. Wright, E. Gruntfest, and D. Webber, 2015: A review of people's behavior in and around floodwater. Wea. Climate Soc., 7, 321-332, CrossRef.

Benjamin, S. G., G. A. Grell, J. M. Brown, T. G. Smirnova, and R. Bleck, 2004a: Mesoscale weather prediction with the RUC hybrid isentropic-terrain-following coordinate model. Mon. Wea. Rev., 132, 473-494, CrossRef.

, and Coauthors, 2004b: An hourly assimilation forecast cycle: The RUC. Mon. Wea. Rev., 132, 495-518, CrossRef.

, and Coauthors, 2016: A North American hourly assimilation and model forecast cycle: The Rapid Refresh. Mon. Wea. Rev., 144, 1669-1694, CrossRef.

Blier, W., and K. A. Batten, 1994: On the incidence of tornadoes in California. Wea. Forecasting, 9, 301-315, CrossRef.

Bright, D. R., M. S. Wandishin, R. E. Jewell, and S. J. Weiss, 2005: A physically based parameter for lightning prediction and its calibration in ensemble forecasts. Preprints, Conf. on Meteorological Applications of Lightning Data, San Diego, CA, Amer. Meteor. Soc., CD-ROM, 4.3, CrossRef.

Carlson, T. N., S. G. Benjamin, G. S. Forbes, and Y.-F. $\mathrm{Li}$, 1983: Elevated mixed layers in the severe-storm environment - conceptual model and case studies. Mon. Wea. Rev., 111, 1453-1473, CrossRef.

Chisholm, A. J., 1973: Alberta hailstorms, Part I: Radar case studies and airflow models. Meteor. Monogr., No. 36, Amer. Meteor. Soc., 1-36.

Cifelli, R., N. Doesken, P. Kennedy, L. D. Carey, S. A. Rutledge, C. Gimmestad, and T. Depue, 2005: The community collaborative rain, hail, and snow network: Informal education for scientists and citizens. Bull. Amer. Meteor. Soc., 86, 1069-1077, CrossRef.

Edwards, R., and R. L. Thompson, 1998: Nationwide comparisons of hail size with WSR-88D vertically integrated liquid water and derived thermodynamic sounding data. Wea. Forecasting, 13, 277-285, CrossRef.

Holets, S., and R. N. Swanson, 1981: High-inversion fog episodes in central California. J. Appl. Meteor., 20, 890899, CrossRef.

Jauernic, S. T., and M. S. Van Den Broeke, 2016: Perceptions of tornadoes, tornado risk, and tornado safety actions and their effects on warning response among Nebraska undergraduates. Natural Hazards, 80, 329-350, CrossRef.

Johnson, A. W., and K. E. Sugden, 2014: Evaluation of sounding-derived thermodynamic and wind-related parameters associated with large hail events. Electronic J. Severe Storms Meteor., 9 (5). [Available online at http://www.ejssm.org/ojs/index.php/ejssm/article/ viewArticle/137].
Kalina, E. A., K. Friedrich, B. C. Motta, W. Deierling, G. T. Stano, and N. N. Rydell, 2016: Colorado plowable hailstorms: Synoptic weather, radar, and lightning characteristics. Wea. Forecasting, 31, 663-693, CrossRef.

Lemon, L. R., 1980: Severe storms radar identification techniques and warning criteria. National Severe Storms Forecast Center Tech. Rep. NWS NSSFC-3, 35 pp.

Lindley, T. T., A. R. Anderson, V. N. Mahale, T. S. Curl, W. E. Line, S. S. Lindstrom, and A. S. Bachmeier, 2016: Wildfire detection notifications for impact-based decision support service in Oklahoma using geostationary super rapid scan satellite imagery. J. Operational Meteor., 4 (14), 182-191, CrossRef.

Mann, H. B., and D. R. Whitney, 1947: On a test of whether one of two random variables is stochastically larger than the other. Ann. Math. Stat., 18, 50-60, CrossRef.

Mass, C., and B. Dotson, 2010: Major extratropical cyclones of the Northwest United States: Historical review, climatology, and synoptic environment. Mon. Wea. Rev., 138, 2499-2527. [Available online at www. projecteuclid.org/euclid.aoms/1177730491].

Mesinger, F., and Coauthors, 2006: North American Regional Reanalysis. Bull. Amer. Meteor. Soc., 87, 343-360, CrossRef.

Meyer, R. J., J. Baker, K. Broad, J. Czajkowski, and B. Orlove, 2014: The dynamics of hurricane risk perception: Real-time evidence from the 2012 Atlantic hurricane season. Bull. Amer. Meteor. Soc., 95, 1389-1404, CrossRef.

NWS, cited 2018: Your national weather service: Evolving to build a weather-ready nation. [Available online at www.weather.gov/about/wrn].

Obermeier, H. M., and M. R. Anderson, 2014: Verification and analysis of impact-based tornado warnings in the Central Region of the National Weather Service. Electronic J. Severe Storms Meteor., 10 (1), 1-20. [Available online at www.ejssm.org/ojs/index.php/ ejssm/issue/view/56].

Orlanski, I., 1975: A rational subdivision of scales for atmospheric processes. Bull. Amer. Meteor. Soc., 56, 527-530, CrossRef.

Ralph, F. M., P. J. Neiman, and G. A. Wick, 2004: Satellite and CALJET aircraft observations of atmospheric rivers over the eastern North Pacific Ocean during the El Nino winter of 1997/98. Mon. Wea. Rev., 132, 17211745, CrossRef.

, M. D. Dettinger, M. M. Cairns, T. J. Galarneau, and J. Eylander, 2018: Defining "atmospheric river": How the glossary of meteorology helped resolve a debate. Bull. Amer. Meteor. Soc., 99, 837-839, CrossRef.

Redwood Times, cited 2018: Driving on hail is like driving on a sheet of ice. 
Rickard, L. N., Z. J. Yang, J. P. Schuldt, G. M. Eosco, C. W. Scherer, and R. A. Daziano, 2017: Sizing up a superstorm: Exploring the role of recalled experience and attribution of responsibility in judgments of future hurricane risk. Risk Anal., 37, 2334-2349, CrossRef.

Rothfusz, L. P., R. Schneider, D. Novak, K. Klockow, A. E. Gerard, C. Karstens, G. J. Stumpf, and T. M. Smith, 2018: FACETS: A proposed next-generation paradigm for high impact weather forecasting. Bull. Amer. Meteor. Soc., 99, 2025-2043, CrossRef.

Rotunno, R., and J. B. Klemp, 1985: On the rotation and propagation of simulated supercell thunderstorms. $J$. Atmos. Sci., 42, 271-292, CrossRef.

Steenburgh, W. J., 2003: One hundred inches in one hundred hours: Evolution of a Wasatch Mountain winter storm cycle. Wea. Forecasting, 18, 1018-1036, CrossRef.

Takahashi, T., 1993: High ice crystal production in winter cumuli over the Japan Sea. Geophys. Res. Lett., 20, 451454, CrossRef.

, Y. Nagao, and Y. Kushiyama, 1995: Possible high ice particle production during graupel-graupel collisions. J. Atmos. Sci., 52, 4523-4527, CrossRef.

Thompson, R. L., R. Edward, J. A. Hart, K. L. Elmore, and P. Markowski, 2003: Close proximity soundings within supercell environments obtained from the Rapid Update Cycle. Wea. Forecasting, 18, 1243-1261, CrossRef.

Witt, A., M. D. Eilts, G. S. Stumpf, J. T. Johnson, E. D. Mitchell, and K. W. Thomas, 1998: An enhanced hail detection algorithm for the WSR-88D. Wea. Forecasting, 13, 286-303, CrossRef. 